\title{
Hemşirelerde Nütrisyonel Değerlendirmeye İlişkin Tutumun, Nütrisyonel Bakıma İlişkin Bilgi Düzeyi ve Algılanan Bakım Kalitesinin Belirlenmesi
}

\section{Determination the Attitude toward the Nutritional Assessment, the Level of Knowledge of Nutritional Care and the Perceived Quality of Care among Nurses}

\author{
Tuğba Çoşğun ${ }^{1}$, Öznur Gürlek Kısacık ${ }^{1 *}$ \\ ${ }^{1}$ Afyonkarahisar Devlet Hastanesi, Destek ve Kalite Hizmetleri Müdürlüğü, Afyonkarahisar, Türkiye. \\ ${ }^{2}$ Afyonkarahisar Sağlık Bilimleri Üniversitesi, Sağlık Bilimleri Fakültesi, Hemşirelik Esasları Anabilim Dalı, \\ Afyonkarahisar, Türkiye.
}

\author{
e-mail: kisacik@aku.edu.tr, tugba.ercosgun@gmail.com \\ ORCID: 0000-0002-1317-3141 \\ ORCID: 0000-0001-9210-455X \\ *Sorumlu yazar/ Corresponding Author: Öznur Gürlek Kısacık
}

Gönderim Tarihi / Received: 10.07.2020

Kabul Tarihi / Accepted: 13.02.2021

DOI: $10.34087 /$ cbusbed. 767803

\section{Öz}

Giriş ve Amaç: Bu araştırma, hemşirelerin nütrisyonel değerlendirmenin önemine ilişkin tutumlarını, nütrisyonel bakıma ilişkin bilgi düzeylerini ve nütrisyonel bakım kalitesi algılarını değerlendirmek amacıyla yapıldı.

Gereç ve Yöntemler: Tanımlayıcı ve kesitsel tipteki bu araştırma 15 Mart 2019-30 Haziran 2019 tarihleri arasında Afyonkarahisar ilindeki bir devlet ve bir üniversite hastanesinde çalışan 590 hemşire ile yürütüldü. Verilerin toplanmasında Hemşire Bilgi Formu ve Hemşirelerde Nütrisyonel Değerlendirmenin Önemini, Nütrisyonel Bakıma İlişkin Bilgi Düzeyini ve Algılanan Nütrisyonel Bakım Kalitesini Değerlendirme Ölçeği kullanıldı.

Bulgular: Hemşirelerin nütrisyonel değerlendirmenin önemine ilişkin tutum puan ortalaması $23.41 \pm 2.85$, nütrisyonel bakıma yönelik bilgi düzeyi puan ortalaması $25.95 \pm 3.45$, algılanan nütrisyonel bakım kalitesi puan ortalaması 33.70 \pm 5.51 olarak bulundu. CHAID analizi sonuçları; hemşirelerin tutum ve algılanan nütrisyonel bakım kalitesi puanları üzerinde etkili olan en önemli değişkenin çalıştıkları klinik olduğunu (sırasıyla; $F=12.307 ; \mathrm{F}=36.445$; $\mathrm{p}<0.001)$, bilgi düzeyleri puanlarının ise en çok eğitim düzeyi değişkeninden etkilendiğini gösterdi $(\mathrm{F}=9.257$; $\mathrm{p}=0.002$ ).

Sonuç: Araştırmadan elde edilen bulgulara göre; hemşirelerin, nütrisyonel değerlendirmenin önemine ilișkin olumlu bir tutuma sahip oldukları, ancak nütrisyonel bakıma ilişkin bilgi düzeylerinin yeterli olmadığı ve kendi kliniklerinde hastalara sunulan nütrisyonel bakım kalitesini yeterince olumlu değerlendirmedikleri söylenebilir. Hemşirelerin nütrisyonel bakımdaki yetkinliklerinin geliştirilmesi önerilmektedir.

Anahtar kelimeler: Bakım Kalitesi, Hemşire, Nütrisyon, Nütrisyonel Bakım, Nütrisyonel Değerlendirme.

\section{Abstract}

Objective: The aim of this study was conducted to evaluate the attitudes of nurses toward the importance of nutritional assessment, their level of knowledge of nutritional care, and the nurse-perceived quality of nutritional care.

Materials and Methods: This descriptive and cross-sectional study was conducted between 15 March 2019 and 30 June 2019 with 590 nurses working in a state and university hospital in the Afyonkarahisar province of Turkey. The data were collected using the Nurse Information Form and the Questionnaire for Evaluating the Importance of Nutritional Assessment, the Level of Nutritional Care Knowledge and the Perceived Quality of Care among Nurses. Results: The mean score was $23.41 \pm 2.85$ for the nurses' attitudes toward the importance of nutritional assessment, $25.95 \pm 3.45$ for the level of knowledge of nutritional care among nurses, and $33.70 \pm 5.51$ for the nurse-perceived quality of nutritional care. According to CHAID analysis results, the most important variable affecting nurses' attitudes and perceived nutritional care quality scores was the clinic they work in $(\mathrm{F}=12.307 ; \mathrm{F}=36.445 ; \mathrm{p}<0.001$ respectively) and their knowledge level scores were mostly affected by the education level variable $(F=9.257 ; p=0.002)$. 
Conclusion: It was determined that nurses have a positive attitude toward the importance of nutritional assessment; however, they lack a sufficient level of knowledge in nutritional care, and do not evaluate the quality of care provided to patients at their clinics as sufficiently favorable. It is recommended that to improve the nurses' competence in nutritional care.

Keywords: Care Quality, Nurse, Nutrition, Nutritional Assessment, Nutritional Care.

\section{Giriș}

Nütrisyon, en temel insan gereksinimlerinden biri olarak kabul edilmektedir. Dünya genelindeki birçok sağlık kurumunda hastaların hastaneye yatışı öncesinde ya da hastaneye yattığ dönemde yetersiz beslendiği göz önünde bulundurulduğunda, nütrisyon kritik öneme sahip aynı zamanda da kontrol edilebilir bir risk faktörüdür $[1,2]$. Hastanede tedavi altındaki hastalar için daha fazla klinik öneme sahip olan malnütrisyon, enerji, protein veya diğer besin maddelerinin eksikliği olarak kabul edilmektedir [3-5]. Hastane kaynaklı malnütrisyon, mortalite oranında artma, hastanede kalış süresinde uzama, yaşam kalitesinde düşme, komplikasyon oranlarında ve bakım maliyetinde artışa katkıda bulunan ciddi bir yüktür [6-9]. Yapılan çalışmalar hastanede yatan hastalarda \%10-60 arasında değișen bir prevalansla malnütrisyon görüldüğüne dair kanıtlar sunmaktadır [2,10-13]. Malnütrisyonun neden olabileceği olumsuz klinik sonuçlar göz önüne alındığında, hastaneye yatışta hastaların nütrisyonel durumlarının değerlendirilmesi ve malnütrisyon riskinin tanılanması, hastanın ihtiyac duyduğu nütrisyon desteğine zamanında başlanabilmesi için kritik öneme sahiptir [14]. Klinik klavuzlar, bireyselleştirilmiş nütrisyonel değerlendirmenin önemini, disiplinler arası işbirliğine dayalı nütrisyon desteğini ve hastaların nütrisyonel durumlarının izlenmesini vurgulamaktadır [15]

Etkin bir nütrisyonel durum değerlendirmesinin, malnütrisyon oranında azalma ile ilişsili olduğu, nütrisyon desteğine yönelik müdahalelerin, hastaların hastanede kalış süresinde kısalma ve sağlık bakım maliyetlerinde azalma sağladığı bilinmektedir $[5,16,17]$ Nütrisyonun klinik önemini vurgulayan birçok çalışmaya rağmen, malnütrisyon riski altındaki hastaların tespit edilemediği dolaylı olarak ta hastaya ihtiyacı olan nütrisyon desteğinin sağlanamadığ $[12,18]$. Sağlık profesyonellerinin nütrisyon desteğine ilişkin bilgi eksiklikleri, iş yüklerinin fazla olması, nütrisyonel bakımdaki sorumluluklarının farkında olmamaları, hastaların nütrisyonel durumlarının ele alınmasının önemine vurgu yapan bir sistemin ya da kurumsal kültürün eksikliği gibi faktörler, hastanede yatan hastalar için nütrisyon desteğinin ve nütrisyonel bakımı profesyonelce ele alınmasının önündeki engellerdir [19,20]. Sağlık hizmetlerinin sunumunda, önemli rol ve fonksiyonlara sahip hemşireler, hastanede yatan hastalar için nütrisyonel bakım kalitesinin iyileştirilmesinde en önemli ekip üyesi olarak kabul edilmektedir. Hemşirelerin günün yirmi dört saati hastalarına sundukları yakın gözlem ve kritik değerlendirmeleri, malnütrisyon riski altında olan bir hastanın erken dönemde tanılanmasını ve ihtiyaç duyduğu nütrisyonel bakımı almasını sağlayabilir [4,14,20,21]. Ancak, hemşirelerin nütrisyonel bakım kapsamındaki rollerini yerine getirebilmeleri için, konu ile ilgili yeterli bilgiye ve sorumluluğa sahip olmaları, aynı zamanda da nütrisyonel bakımın, hastalar için önemini algılamaları gereklidir $[15,21,22]$.

Ülkemizde, hastalara nütriyon desteğinin profesyonel bir ekip tarafından sağlanmasına yönelik uygulamalar, bir hasta bakım standardı olarak kabul edilmiştir [23]. Buna ek olarak, hastanın nütrisyonel gereksiniminin belirlenerek, ihtiyacı olan nütrisyonel bakımın planlanması ve uygulanması hemşirelerin yasal sorumlulukları arasında tanımlanmıştır [24]. Bu gelişmelere rağmen yapılan sınırlı sayıdaki çalışmalar; nütrisyonun özellikle de hastanın nütrisyonel durumunun değerlendirilmesinin hemşirelik uygulamalarının bir parçası olarak görülmediğine dikkat çekmektedir $[25,26]$. Diğer yandan, ülkemizde hemşirelerin, hastanın nütrisyonel durumunun değerlendirilmesinin önemine ilişkin tutumlarını, nütrisyonel bakıma yönelik bilgi düzeylerini ve kendi kliniklerinde hastalara sunulan nütrisyonel bakımının kalitesini nasıl algıladıklarını değerlendiren bir çalışmaya rastlanamamıştır. $\mathrm{Bu}$ gereksinimden yola çıkarak planlanan bu araştırmanın sonuçlarının, hastaların nütrisyonel durumlarının değerlendirilmesinde ve nütrisyonel bakımda önemli rol ve fonksiyonlara sahip hemşirelerin, bu konudaki farkındalık ve sorumluluklarının arttırılmasına katkı sağlayacağı düşünülmektedir.

$\mathrm{Bu}$ çalışmada, hemşirelerin nütrisyonel değerlendirmenin önemine ilișkin tutumlarını, nütrisyonel bakıma ilişkin bilgi düzeylerini ve nütrisyonel bakım kalitesini algılarını belirlemek, bununla birlikte hemşirelerin tutum, bilgi düzeyi ve nütrisyonel bakım kalitesi algılarını yordayan değişkenleri incelenmek amaçlanmıştır.

\section{Materyal ve Metot}

\subsection{Araştırma Tipi}

$\mathrm{Bu}$ araştırma tanımlayıcı ve kesitsel tipte bir çalışmadır. 2.2. Araştırmanın Evreni ve Örneklemi

Araştırmanın evrenini 15.03.2019-01.06.2019 tarihleri arasında Afyonkarahisar ilinde yer alan bir devlet hastanesi ve üniversite hastanesinin dahili, cerrahi, pediatri ve kadın hastalıkları ve doğum klinikleri ile yoğun bakım ünitelerinde çalışan 966 hemşire oluşturdu. Nütrisyonel değerlendirme ve nütrisyon desteğine yönelik uygulamaların, primer olarak hemşirelik işlevleri kapsamında yer almadığı, kan alma üniteleri, ameliyathane, acil servis ve poliklinik hizmetlerinde çalışan ( $\mathrm{n}=275)$, araştırmanın yapıldı ğ 1 kurumda bir aydan daha kısa süredir çalışan $(n=30)$, belirtilen tarih aralığında raporlu/izinli olan $(n=42)$ hemşireler, araştırma kapsamı dışında bırakıldı. Dahil edilme kriterlerine uygun olan 619 hemșireden araștırmaya katılmayı sözlü ve gönüllü olarak kabul ettiğini bildiren 
ve veri toplama formlarını eksiksiz dolduran toplam 590 hemşire araştırmanın örneklemini oluşturdu. Hemşirelerin araştırmaya katılım oranı \%95.3'tür.

2.3.Araştırma Verilerinin Toplanması

\subsubsection{Veri Toplama Araçları}

Araştırma verilerinin toplanmasında "Hemşire Bilgi Formu", "Hemşirelerde Nütrisyonel Değerlendirmenin Önemini, Nütrisyonel Bakıma İlişkin Bilgi Düzeyini ve Algılanan Nütrisyonel Bakım Kalitesini Değerlendirme Ölçeği" kullanıldı.

\subsubsection{Hemşire Bilgi Formu}

Araştırmacılar tarafından literatür taraması [14,25-27] ve uzman görüşü alınarak oluşturulan, araştırmaya katılan hemşirelerin sosyo-demografik özellikleri ile nütrisyon desteği ve nütrisyonel bakım ile ilişkili eğitim alma durumları, eğitim ihtiyaçları, nütrisyonel bakıma yönelik hemşirelik uygulamaları hakkındaki verileri elde etmeyi amaçlayan toplam 11 sorudan oluşmaktadır.

2.3.1.2.Hemșirelerde Nütrisyonel Değerlendirmenin Önemini, Nütrisyonel Bakıma İlişkin Bilgi Düzeyini ve Algılanan Nütrisyonel Bakım Kalitesini Değerlendirme Ölçeğ $i$

Theilla ve ark. (2016) tarafından geliştirilen [15] ülkemiz için geçerlik ve güvenirlik çalışması Kısacık ve ark. (2019) tarafından yapılan ölçek üç bölümden oluşmaktadır [28]. Birinci bölüm; nütrisyonel değerlendirmenin klinik önemine ilişkin hemşirelerin tutumlarını ve nütrisyonel değerlendirmeyi hemşirelik bakımının temel bir bileşeni olarak görme durumlarını değerlendiren yedi ifadeyi içermektedir. İfadeler 4'lü likert tipinde "kesinlikle katılmiyorum" (1), "katılmıyorum" (2), "katılıyorum" (3), "kesinlikle katılıyorum" (4) olarak puanlanmaktadır. Ölçeğin bu bölümünden alınabilecek puan aralığı 7-28'dir. Bu bölümden alınan puanın yüksek olması, hastanın nütrisyonel durumunun değerlendirilmesinin önemine ve nütrisyonel değerlendirmenin hemşirelik işlevleri arasında kabul edilmesine ilișkin hemşirelerin daha olumlu bir tutuma sahip oldukları şeklinde yorumlanır. Ölçeğin ikinci bölümünde hemşirelerin, nütrisyone bakıma ilişkin bilgi düzeylerini değerlendiren 10 adet ters puanlanan ifade bulunmaktadır. İfadeler 4'lü likert tipinde "kesinlikle katılmıyorum" (4), "katılmıyorum" (3), "katılıyorum" (2), "kesinlikle katılıyorum" (1) olarak puanlanmaktadır. $\mathrm{Bu}$ bölümdeki 10 maddeden alınabilecek puan arttıkça, hemşirelerde daha yüksek bir nütrisyonel bakım bilgisini yansıtmaktadır. Ölçeğin bu bölümünden alınabilecek puan aralığı 10-40'tır. Üçüncü bölüm; hemşirelerin, çalıştıkları kliniklerde hastalara sunulan nütrisyonel bakımın kalitesini nasıl algıladıklarını değerlendiren dokuz adet ifadeden oluşmaktadır. İfadeler 5'li likert tipinde "kesinlikle katılmıyorum" (1), "katılmıyorum" (2), "kararsızım" (3) "katılıyorum" (4), "kesinlikle katılıyorum" (5) olarak puanlanmaktadır. Ölçeğin bu bölümünden alınabilecek puan aralığı 9-45'tir. Bu bölümdeki dokuz maddeden alınabilecek daha yüksek puan, hemşirelerin, çalıştıkları birimlerde hastalara sunulan nütrisyonel bakımın kalitesini daha olumlu olarak değerlendirdiklerini yansıtmaktadır. Ölçekten elde edilebilecek toplam bir puan bulunmayıp, üç bölüm birbirinden bağımsız olarak değerlendirilmektedir [15,28]. Theilla ve ark. (2016) ölçeğin bölümlerinin Cronbach's alpha katsayılarını sırasıyla $0.82 ; 0.79 ; 0.90$ olarak bildirmiştir [15]. Türkçe geçerlik ve güvenirlik çalışmasında Cronbach's alpha katsayıs1, tutum boyutu için $\alpha=0.82$, bilgi düzeyi boyutu için $\alpha=0.63$, algılanan bakım kalitesi boyutu için $\alpha=0.85$ olarak bulunmuş, test-tekrar test toplam puanları arasındaki korelasyon katsayıları 0.89-0.92 arasında tespit edilmiştir [28]. Bu çalışmada Cronbach's alpha katsayısı, tutum boyutu için $\alpha=0.85$, bilgi düzeyi boyutu için $\alpha=0.67$, algılanan bakım kalitesi boyutu için $\alpha=0.87$ olarak bulunmuştur.

\subsection{Araştırma Verilerinin Toplanması}

Araştırmanın yapılabilmesi için gerekli izinler alındıktan sonra, araştırmanın yürütüldüğü her iki kurumda çalışan hemşirelere ulaşmak için periyodik olarak gündüz (saat: 11.00-14.00) ve gece (saat: 20.00-22.00) ziyaretleri planlanarak, araştırmacı tarafindan hem gündüz hem de gece vardiyasında çalışan hemşirelere ulaşıldı. Dahil edilme kriterlerine uygun olan hemşirelere çalışmanın amacı konusunda bilgilendirme yapılarak katılmayı kabul eden hemşirelerin yazılı ve sözlü onamları alındı. Veri toplama formları her bir hemşire için teslim edildikten sonra, hemşirelerin ziyaret süresince uygun oldukları zaman diliminde isimsiz olarak veri toplama formlarını doldurmaları ve kapalı zarf içine koyarak teslim etmeleri istendi. Verilerin toplanması ortalama 2030 dakikalık bir süreyi ald.

\subsection{Verilerin Değerlendirilmesi}

Araştırma verilerin analizi SPSS versiyon 22.0 (Armonk, NY: IBMCorp) paket programı ile yapıldı. Araştırmadaki sürekli değişkenlere ait tanımlayıcı istatistikler ortalama, standart sapma, minimum ve maksimum değerleriyle, kategorik değişkenlere ait tanımlayıcı istatistikler frekans ve yüzde ile gösterildi. Hemşirelerin tutum, bilgi düzeyi ve algılanan nütrisyonel bakım kalitesi puanları üzerinde etkili olan değişkenleri incelemek amacıyla, araştırma örneklemini hem sinıflayan hem de regresyon analizini bir arada uygulayan çok değişkenli bir istatistiksel yaklaşım tekniği olan CHAID (karar ağaçları yaklaşım tekniği) analizi uygulandı. CHAID analizi, bağımsız değişkenlere ilişkin veri kümelerini, bağımlı değişkeni en iyi açıklayacak biçimde detaylı homojen alt gruplara bölen bir istatistiksel yöntemdir [29,30]. Bu araştırmada CHAID analizi ile bağımlı değişkenleri (tutum, bilgi düzeyi ve algılanan nütrisyonel bakım kalitesi puanları) etkileyen bağımsız değişkenlere ait alt düzeyler ve alt düzeyler arasındaki ilişkiler elde edilerek, karar ağaçları yaklaşımı ile gösterildi. Bağımsız değişkenlerin, bağımlı değişken üzerindeki anlamlı ilişkileri için etki büyüklüğünün hesaplanmasında eta kare ( $\eta 2)$ değeri, ölçek boyutlarının birbirleri ile ilişki boyutunun gücü için pearson korelasyon katsayısı (r) kullanıldı. Cohen (1988) tarafindan önerilen kriterlere göre, $0.010 \leq \eta 2<0.039$ "küçük etki", $0.060 \leq \eta 2<0.110$ "orta etki", $\eta 2 \geq 0.140$ "büyük etki" olarak kabul edildi [30]. Yapılan testlerde istatistiksel anlamlılık sınırı için alfa düzeyi $\mathrm{p}<0.05$ olarak kabul edildi

\subsection{Araştırmanın Etik Yönü}


$\mathrm{Bu}$ araştırmanın yürütülebilmesi için belirtilen hastanelerin yöneticilerinden yazılı kurum izni, bir üniversitenin Klinik Araştırmalar Etik Kurulu'ndan 2019/81 tarih ve sayılı etik kurul izni alındı. Ayrıca araştırmaya dahil edilme kriterlerine uygun olan tüm hemşirelere çalışmanın amacı konusunda bilgilendirme yapılmış, araştırmaya dahil olup olmak istemedikleri sorularak, gönüllülüğün esas olduğu vurgulandı. Araştırmaya katılmayı kabul eden tüm hemşirelerin yazılı ve sözlü onamları alındı. Bu araştırma, Helsinki Deklarasyonu Prensipleri'ne uygun olarak yürütüldü.

\section{Bulgular ve Tartışma}

3.1. Hemşirelerin Genel Özelliklerine İlişkin Bulgular Hemşirelerin yaş ortalaması $30.97 \pm 7.77$, meslekte çalışma yılı ortalaması 9.34 \pm 7.62 , kurumda çalışma yılı ortalaması $5.48 \pm 5.80$, bulundukları klinikte çalışma yılı ortalaması $3.37 \pm 3.84$ olarak bulundu. Hemşirelerin \%79.3'ünün $(\mathrm{n}=468)$ kadın, \%58'inin $(\mathrm{n}=342)$ lisans mezunu olduğu saptandı. Araştırma kapsamına dahil edilen hemşirelerin \%62'sinin $(n=366)$ daha önce nütrisyon desteğine yönelik eğitim aldığ $(n=138)$ bu eğitimi son 1 yıl içerisinde ve hizmet içi eğitime katılarak $(\% 81.9, \quad \mathrm{n}=335)$ aldığ 1 saptandı. Araştırmaya katılan hemşirelerin sadece \%9'unun $(n=53)$ nütrisyonel bakıma ilişkin mevcut bilgilerini yeterli bulduğu belirlenirken, \%71.9'u $(n=424)$ bu yeterliliği "kısmen" olarak ifade etti. Hemşireler tarafindan en fazla oranla bildirilen bilgi kaynağ $1(\% 46.3, n=431)$ uygulama alanındaki deneyimdi. Hemşirelerin nütrisyon desteği ile ilgili eğitim gereksinimine yönelik bulgular incelendiğinde, birden fazla konuda eğitim ihtiyacı olduğunu bildiren hemşirelerin çoğunlukla "hastanın beslenme gereksiniminin hesaplanması", $\quad(\% 16.8$, $\mathrm{n}=346$ ), "malnütrisyon riskinin değerlendirilmesi ve kullanılan yöntemler"(\%15.4, n=318) gibi konularda eğitime ihtiyaç duydukları saptandı.

3.2.Hemşirelerin Tutumlarına İlişkin Bulgular

Araştırmaya katılan hemşirelerin, nütrisyonel değerlendirmenin önemine ilişkin tutum puan ortalamasının 23.41 \pm 2.85 (7-28 puan aralığında) olduğu saptand1. Hemşirelerin ölçek maddelerine verdikleri yanıtların dağılımı incelendiğinde, "hasta bakımında ilk nütrisyonel değerlendirme önemlidir" (3.57 \pm 0.51$)$, "hemşirelerin, nütrisyonel durumu değerlendirmesi ve izlemesi hastanın iyileşmesini hızlandırır" (3.45 \pm 0.53$)$ ifadelerine verdikleri "kesinlikle katılıyorum/katılıyorum" yanıtları ile tutum puanlarının daha yüksek olduğu belirlenirken, en düșük tutum puanının "yatışı yapıldığında hastaları tartmak önemlidir" (3.14 \pm 0.63$)$ ifadesine ait olduğu saptandı (Tablo 1).

Tablo 1. Nütrisyonel Değerlendirmenin Önemine İlişkin Hemşirelerin Tutum Puanlarının Dağılımı (n: 590)

\begin{tabular}{|c|c|c|c|c|c|c|c|c|c|}
\hline \multirow{2}{*}{$\begin{array}{l}\text { Ortalama } \pm \text { SS } \\
23.41 \pm 2.85\end{array}$} & & \multicolumn{3}{|c|}{ Minimum } & \multicolumn{2}{|c|}{ Maksimum } & \multicolumn{3}{|c|}{ Puan aralığ } \\
\hline & & & 12 & & & 8 & & & \\
\hline Maddeler & \multirow[t]{2}{*}{ Ortalama \pm SS } & \multicolumn{2}{|c|}{$\begin{array}{c}\text { Kesinlikle } \\
\text { Katılıyorum }\end{array}$} & \multicolumn{2}{|c|}{ Katılıyorum } & \multicolumn{2}{|c|}{ Katılmıyorum } & \multicolumn{2}{|c|}{$\begin{array}{c}\text { Kesinlikle } \\
\text { Katılmıyorum }\end{array}$} \\
\hline & & $\mathrm{n}$ & $\%$ & $\mathrm{n}$ & $\%$ & $\mathrm{n}$ & $\%$ & $\mathrm{n}$ & $\%$ \\
\hline $\begin{array}{ll}\text { 1. Hasta bakımında ilk nütrisyonel } \\
\text { değerlendirme önemlidir }\end{array}$ & $3.57 \pm 0.51$ & 341 & 57.8 & 242 & 41.0 & 7 & 1.2 & - & - \\
\hline $\begin{array}{l}\text { 2. Hastanın nütrisyonel durumunun izlenmesi } \\
\text { hemşirelik bakımının temel bir unsurudur }\end{array}$ & $3.36 \pm 0.58$ & 240 & 40.7 & 324 & 54.9 & 22 & 3.7 & 4 & 0.7 \\
\hline $\begin{array}{l}\text { 3. Hasta yemeğini yemediğinde, hemşire bu } \\
\text { durumu doktora bildirmekten sorumludur }\end{array}$ & $3.28 \pm 0.68$ & 236 & 40.0 & 288 & 48.8 & 60 & 10.2 & 6 & 1.0 \\
\hline $\begin{array}{l}\text { 4. Yatışı yapıldığında hastaları tartmak } \\
\text { önemlidir }\end{array}$ & $3.14 \pm 0.63$ & 162 & 27.5 & 353 & 59.8 & 72 & 12.2 & 3 & 0.5 \\
\hline $\begin{array}{l}\text { 5. Hastanede yatış süresince nütrisyonel } \\
\text { değerlendirmenin her hafta tekrarlanmas } \\
\text { önemlidir }\end{array}$ & $3.18 \pm 0.58$ & 163 & 27.6 & 372 & 63.1 & 55 & 9.3 & - & - \\
\hline $\begin{array}{l}\text { 6. } \begin{array}{l}\text { Hemşirelerin, nütrisyonel } \\
\text { değerlendirmesi ve izlemesi }\end{array} \\
\text { iyilessmesini hızlandırır }\end{array}$ & $3.45 \pm 0.53$ & 277 & 46.9 & 301 & 51.0 & 12 & 2.0 & - & - \\
\hline $\begin{array}{l}\text { 7. Hemşirelik bakımı, hastaların nütrisyonel } \\
\text { durumu üzerinde önemli bir etkiye sahiptir }\end{array}$ & $3.43 \pm 0.53$ & 268 & 45.4 & 311 & 52.7 & 10 & 1.7 & 1 & 0.2 \\
\hline
\end{tabular}


Hemşirelerin tutum puanları üzerinde etkili olan bağımsız değişkenlere ait ilişkiler karar ağacı ile sinıflanarak, elde edilen diyagram Şekil 1'de sunuldu. Hemşirelerin nütrisyonel değerlendirmenin önemine ilişkin tutum puanlarının bağımlı değişken olarak alındığı modelde, çalışılan klinik, nütrisyon desteğine yönelik eğitim alma ve çalışılan kurum, modelin bağımsız değişkenlerini oluşturdu. CHAID analizi sonucuna göre; hemşirelerin tutum puanlarındaki artış üzerinde etkili olan en önemli değişkenin hemşirelerin çalıştıkları klinik olduğu, yoğun bakım ünitesinde ve pediatri kliniklerinde çalışan hemşirelerin tutum puanlarının, dahili-cerrahi ve kadın doğum kliniklerinde çalışan hemşirelerden anlamlı olarak daha yüksek olduğu belirlendi $(\mathrm{F}=12.307$; $\mathrm{p}<0.001)$. Anlamlı bulunan çalışılan klinik değişkenin orta düzeyde bir etki büyüklüğüne sahip olduğu saptand $1 \quad(\eta 2=0.06)$. Hemşirelerin tutum puanlarında ikincil düzeyde etkili olan bağımsız değişkenlerin orta düzeyde bir etki büyüklüğü ile nütrisyon desteğine ilişkin eğitim alma ( $\eta 2=0.08)$ ve küçük bir etki büyüklügüne sahip olan çalışılan kurum $(\eta 2=0.05)$ değişkenleri olduğu belirlendi. Şekil 1'deki diyagram incelendiğinde, nütrisyon desteğine ilişkin eğitim almanın yoğun bakım ünitesinde ve pediatri kliniklerinde çalışan hemşirelerin tutum puanlarındaki orta düzeyde bir artışla ilişkili olduğu belirlenirken $(\mathrm{F}=4.617 ; \mathrm{p}=0.003)$, diğer kliniklerde çalışan hemşireler için ise devlet hastanesinde çalışıyor olmanın, üniversite hastanesinde çalışan hemşirelerle kıyaslandığında, hemşirelerin tutum puanlarını küçük bir etki büyüklüğü ile anlamlı olarak arttırdığı saptandı (Şekil 1).

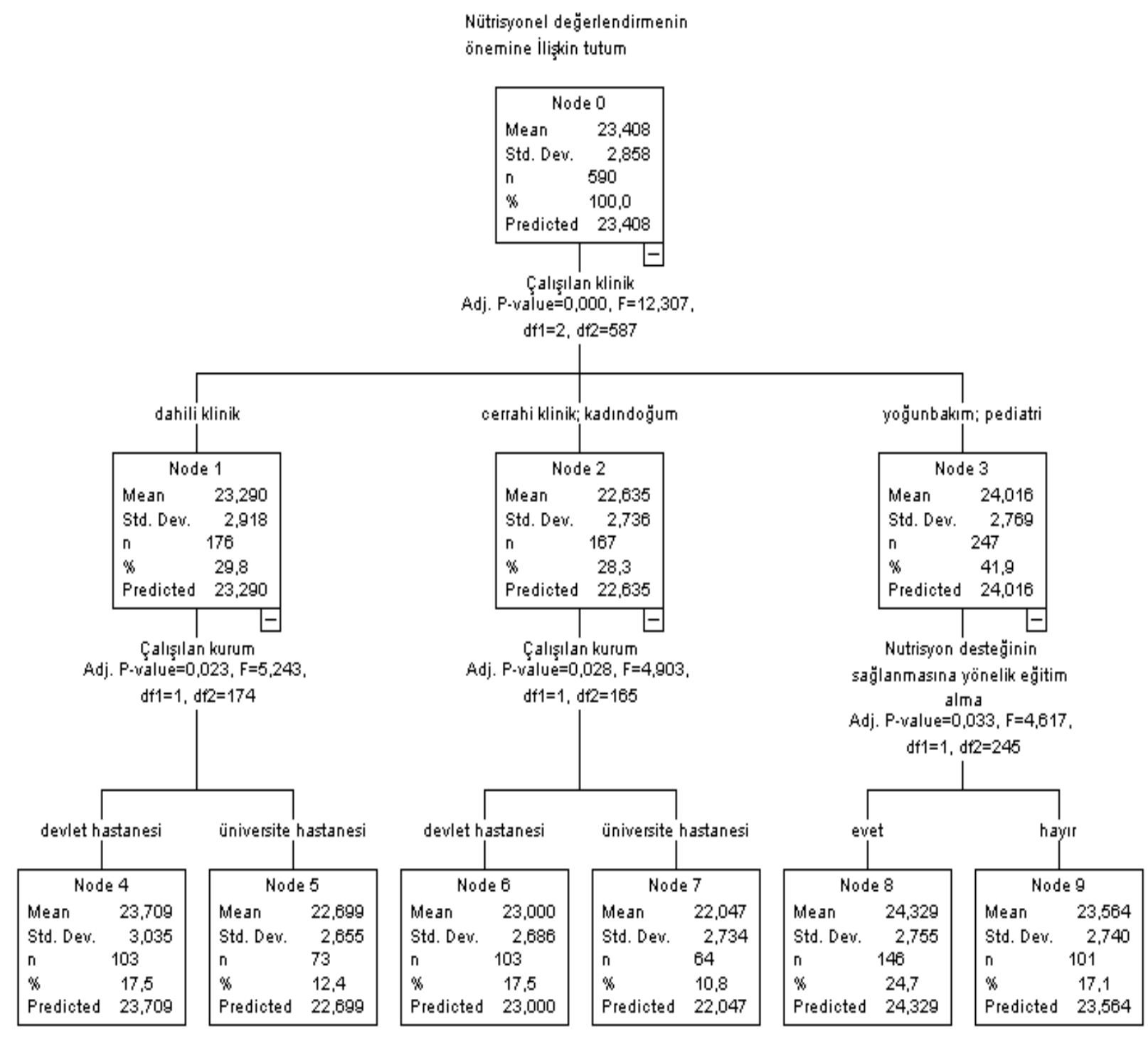

Şekil 1. Hemşirelerin nütrisyonel değerlendirmenin önemine ilişkin tutumlarını etkileyen değişkenler için ağaç diyagram1. 


\subsection{Hemşirelerin Bilgi Düzeylerine İlişskin Bulgular}

Hemşirelerin nütrisyonel bakıma ilişkin bilgi düzeyi puan ortalamas1 $25.95 \pm 3.45$ (10-40 puan aralığında) olarak saptand. Hemşirelerin ölçek maddelerine verdikleri yanıtların dağılımı incelendiğinde, "hastaların hastane yemeğini yememesinin ana nedeni, yemeğin

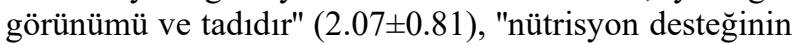
sağlanmasından hemşirelerden ziyade, diyetisyenler sorumludur" (2.18 \pm 0.80$)$ ifadelerine yönelik bilgi düzeyi puanlarının düşük olduğu saptanmışıı (Tablo 2).

Tablo 2. Hemşirelerin Nütrisyonel Bakımına İlişkin Bilgi Düzeyi Puanlarının Dağılımı (n: 590)

\begin{tabular}{|c|c|c|c|c|c|c|c|c|c|}
\hline \multirow{2}{*}{$\begin{array}{c}\text { Ortalama } \pm \text { SS } \\
25.95 \pm 3.45\end{array}$} & & \multirow{2}{*}{\multicolumn{3}{|c|}{$\begin{array}{c}\text { Minimum } \\
10\end{array}$}} & \multirow{2}{*}{\multicolumn{2}{|c|}{$\begin{array}{c}\text { Maksimum } \\
36\end{array}$}} & \multirow{2}{*}{\multicolumn{3}{|c|}{$\begin{array}{c}\text { Puan aralığı } \\
10-40\end{array}$}} \\
\hline & & & & & & & & & \\
\hline \multirow[t]{2}{*}{ Maddeler } & \multirow[t]{2}{*}{$\begin{array}{l}\text { Ortalama } \\
\text { SS }\end{array}$} & \multicolumn{2}{|c|}{$\begin{array}{c}\text { Kesinlikle } \\
\text { Katılıyorum }\end{array}$} & \multicolumn{2}{|c|}{$\begin{array}{l}\text { Katılıyoru } \\
\mathbf{m}\end{array}$} & \multicolumn{2}{|c|}{ Katılmıyorum } & \multicolumn{2}{|c|}{$\begin{array}{c}\text { Kesinlikle } \\
\text { Katılmıyorum }\end{array}$} \\
\hline & & $\mathrm{n}$ & $\%$ & $\mathrm{n}$ & $\%$ & $\mathrm{n}$ & $\%$ & $\mathrm{n}$ & $\%$ \\
\hline $\begin{array}{l}\text { 1. Hemşireler, hastaların nütrisyonel } \\
\text { durumundan ziyade hastanın } \\
\text { birincil tanısına odaklanmalıdır }\end{array}$ & $2.38 \pm 0.71$ & 65 & 11.0 & 253 & 42.9 & 256 & 43.4 & 16 & 2.7 \\
\hline $\begin{array}{l}\text { 2. Yemek yemeyi reddeden bir hasta } \\
\text { yemesi için zorlanmamalıdır }\end{array}$ & $2.31 \pm 0.66$ & 49 & 8.3 & 327 & 55.4 & 197 & 33.4 & 17 & 2.9 \\
\hline $\begin{array}{l}\text { 3. Hastaların hastane yemeğini } \\
\text { yememesinin ana nedeni, yemeğin } \\
\text { görünümü ve tadıdır }\end{array}$ & $2.07 \pm 0.81$ & 158 & 26.8 & 251 & 42.5 & 162 & 27.5 & 19 & 3.2 \\
\hline $\begin{array}{l}\text { 4. Nütrisyon desteği, yalnızca tıbbi } \\
\text { tedavi tamamlandıktan sonra } \\
\text { başlatılmalıdır }\end{array}$ & $2.94 \pm 0.66$ & 19 & 3.2 & 90 & 15.3 & 388 & 65.8 & 93 & 15.8 \\
\hline $\begin{array}{l}\text { 5. Nütrisyon desteği kaynak tüketen } \\
\text { ve maliyeti yüksek bir yatırımdır }\end{array}$ & $2.66 \pm 0.71$ & 39 & 6.6 & 169 & 28.6 & 335 & 56.8 & 47 & 8.0 \\
\hline 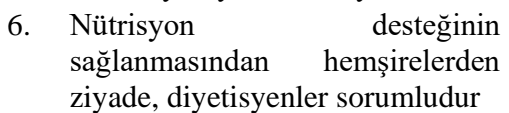 & $2.18 \pm 0.80$ & 125 & 21.2 & 250 & 42.4 & 196 & 33.2 & 19 & 3.2 \\
\hline $\begin{array}{l}\text { 7. Komplikasyonlarından dolay } \\
\text { parenteral beslenmeden } \\
\text { kacınılmalıdır }\end{array}$ & $2.59 \pm 0.66$ & 35 & 5.9 & 197 & 33.4 & 333 & 56.4 & 25 & 4.2 \\
\hline $\begin{array}{l}\text { 8. Obez hastalar (BMI > 30) } \\
\text { malnütrisyon riski altında değildir } \\
\text { ve az miktarda beslenmelidir }\end{array}$ & $2.60 \pm 0.65$ & 27 & 4.6 & 207 & 35.1 & 329 & 55.8 & 27 & 4.6 \\
\hline $\begin{array}{l}\text { 9. Yemek yiyen bir hasta, tıbbi tedavi } \\
\text { için bile rahatsız edilmemelidir. }\end{array}$ & $2.89 \pm 0.74$ & 109 & 18.5 & 330 & 55.9 & 127 & 21.5 & 24 & 4.1 \\
\hline $\begin{array}{l}\text { 10. Aşırı kilolu kanserli hastalarının } \\
\text { kilo kaybetmesi kaçınılmazdır ve } \\
\text { diyetisyene yönlendirilmelerine } \\
\text { gerek yoktur }\end{array}$ & $3.32 \pm 0.66$ & 13 & 2.2 & 26 & 4.4 & 310 & 52.5 & 241 & 40.8 \\
\hline
\end{tabular}

Hemşirelerin nütrisyonel bakıma ilişkin bilgi düzeyi puanları üzerinde etkili olan bağımsız değişkenlere ait ilişkiler karar ağacı ile sınıflanarak, elde edilen diyagram Şekil 2'de sunuldu. Buna göre hemşirelerin bilgi düzeyi puanlarının bağımlı değişken olarak alındığı modelde, eğitim düzeyi, çalışılan kurum, klinikte çalışma yılı, modelin bağımsız değişkenlerini oluşturdu. CHAID analizi sonucuna göre; hemşirelerin nütrisyonel bakım bilgi düzeyi puanlarını etkileyen en önemli birincil değişkenin hemşirelerin eğitim durumu olduğu belirlendi. Şekil 2'deki diyagrama göre; ön lisans eğitim düzeyinden daha yüksek bir eğitime sahip hemşirelerin (lisans ve lisansüstü), lise mezunu ( $<$ ön lisans) olan hemşirelere göre anlamlı olarak daha yüksek bilgi puanına sahip olduğu $(F=9.257 ; p=0.002)$, ancak eğitim düzeyindeki artışın küçük bir etki büyüklüğüne sahip olduğu saptand $1(\eta 2=0.02)$.

Hemşirelerin nütrisyonel bakıma ilișkin bilgi düzeyi puanları üzerinde etkili olan ikincil düzeydeki değişkenin çalışılan kurum olduğu saptandı. Şekil 2'deki diyagrama göre; lisans ve lisansüstü eğitim düzeyindeki hemşireler arasında, devlet hastanesinde çalışıyor olmanın hemşirelerin bilgi düzeylerindeki küçük bir artışa ( $12=$ 0.01 ) etki eden anlamlı bir değişken olduğu belirlenirken $(\mathrm{F}=$ 5.728; $\mathrm{p}=0.017)$, üniversite hastanesinde çalışan hemşirelerde ise 1 yıldan daha az klinikte çalışma yılına sahip olanların bilgi puanlarının daha yüksek olduğu $(\mathrm{F}=$ 7.274; p= 0.039; Şekil 2) ancak, etki büyüklüğü göz önüne alındığında bu farklılığın ihmal edilebilir düzeyde olduğu saptand $1(\eta 2=0.008)$. 


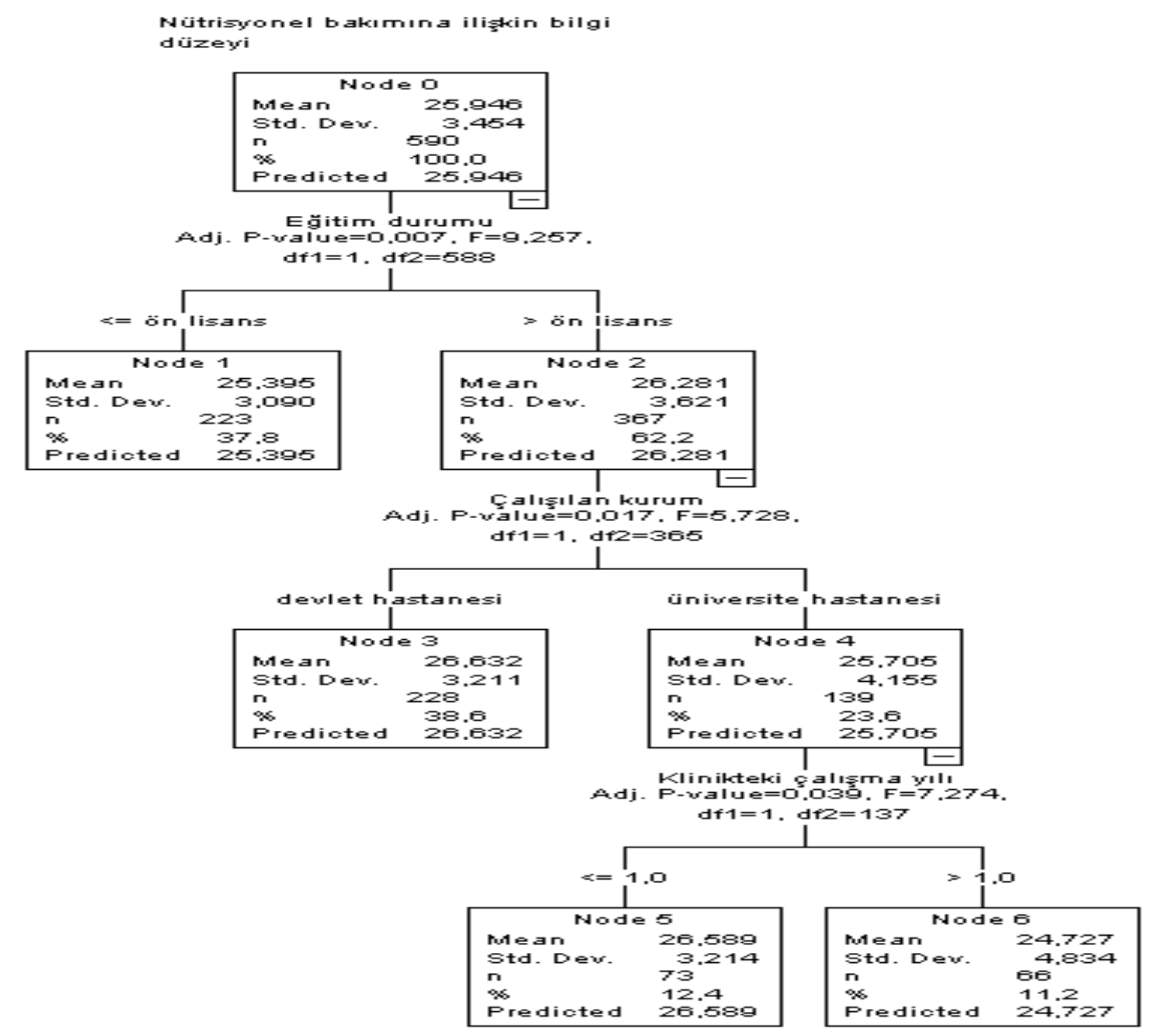

Şekil 2. Hemşirelerin nütrisyonel bakıma ilişkin bilgi düzeylerini etkileyen değişkenler için ağaç diyagramı.

\subsection{Hemşirelerin Nütrisyonel Bakım Kalitesi Algılarına İlişkin Bulgular}

Hemşirelerin nütrisyonel bakım kalitesi algısı puan ortalamas $33.70 \pm 5.51$ (9-45 puan aralığında) olarak saptandı. Hemşirelerin ölçek maddelerine verdikleri yanıtların dağılımı incelendiğinde, en yüksek puan ortalamasinın "hastalar yemeklerini diyet düzenlemelerine uygun olarak alır" (4.15 \pm 0.71$)$ ifadesine ait olduğu belirlenirken, kliniğgimizde; "nütrisyonel değerlendirme düzenli olarak ve profesyonelce yapılır" (3.50 \pm 0.96$)$, "hastalara eksiksiz bir nütrisyon desteği sağlanır" (3.52 \pm 0.92$)$ ifadelerine yönelik puanlarının düşük olduğu saptanmıştır (Tablo 3).

Hemşirelerin nütrisyonel bakım kalitesi algısı puanları üzerinde etkili olan bağımsız değişkenlere ait ilişkiler karar ağacı ile sınıflanarak, elde edilen diyagram Şekil 3'de sunuldu. Hemşirelerin nütrisyonel bakım kalitesi puanlarının bağımlı değişken olarak alındığı modelde, çalışılan klinik, çalışılan kurum ve nütrisyon desteğine yönelik eğitim alma, modelin bağımsız değişkenlerini oluşturdu. CHAID analizi sonucuna göre; çalışılan kliniğin hemşirelerin nütrisyonel bakım kalitesi algısı puanlarındaki artışa etki eden birincil düzeydeki en önemli değişken olduğu belirlenirken, yoğun bakım ünitesinde çalışan hemşirelerin puanlarının anlamlı olarak daha yüksek olduğu $(\mathrm{F}=36.445 ; \mathrm{p}<0.001)$, anlamlı bulunan çalışılan klinik değişkeninin ise orta düzeyde bir etki büyüklüğüne sahip olduğu saptandı $(\eta 2=$ $0.06)$.

Hemşirelerin nütrisyonel bakım kalitesi algısı puanlarında ikincil düzeyde etkili olan bağımsız değişkenin küçük bir etki büyüklüğü ile çalışılan kurum $(\eta 2=0.03)$ olduğu belirlendi. Şekil 3'teki diyagrama göre; hem yoğun bakım ünitesinde $(\mathrm{F}=8.651 ; \mathrm{p}=0.004)$ hem de diğer (dahili-cerrahi-pediatri-kadın doğum klinikleri) kliniklerde $(\mathrm{F}=16.684 ; \mathrm{p}<0.001)$ çalışan hemşireler için, devlet hastanesinde çalışmanın, nütrisyonel bakım kalitesi algısı puanlarındaki küçük bir artışla ilişsili olduğu saptandı.

CHAID analizine göre, hemşirelerin nütrisyonel bakım kalitesi algısı puanlarında üçüncül düzeyde etkili olan bağımsız değişken, orta düzeyde bir etki büyüklüğü ile nütrisyon desteğine yönelik eğitim alma olarak belirlendi $(\eta 2=0.08)$. Şekil 3 'teki diyagrama göre; yoğun bakım 
ünitesi dışındaki birimlerde çalışan hemşirelerin nütrisyonel bakım kalitesi algısı puanlarındaki orta düzeydeki anlamlı bir artışın, nütrisyon desteğine yönelik eğitim alma ile ilişkili olduğu saptandı $(F=21.281$; $\mathrm{p}<0.001)$

Tablo 3. Hemşirelerin Nütrisyonel Bakım Kalitesi Algılarına İlişkin Puanların Dağılımı (n: 590)






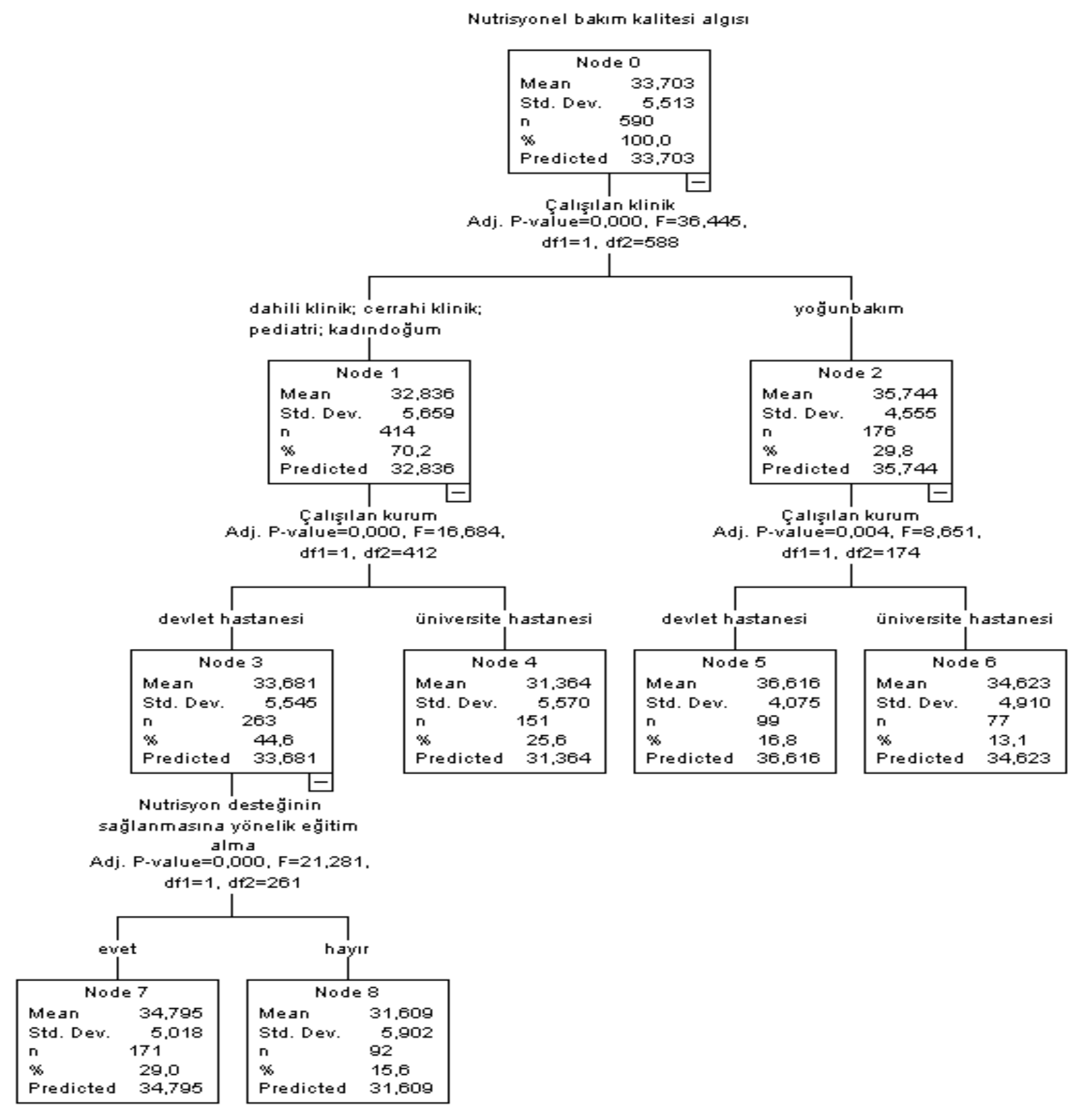

Şekil 3. Hemşirelerin nütrisyonel bakım kalitesi algılarını etkileyen değişkenler için ağaç diyagramı.

\section{5. Ölçek Boyutlarının İlişkilerine Yönelik Bulgular}

Hemşirelerin ölçek boyut puan ortalamalarının birbirlerine ait ilişkiler karar ağacı ile sınıflanarak, elde edilen diyagram Şekil 4'te sunuldu. Buna göre; hemşirelerin nütrisyonel değerlendirmenin önemine ilişkin tutumlarını üzerinde etkili olan en önemli birincil değişkenin algılanan nütrisyonel bakım kalitesi olduğu $(\mathrm{F}=28.256 ; \mathrm{p}<0.001)$, bu iki değişkenin orta düzeyde pozitif yönde bir ilişkili olduğu saptandı $(r=0.309$, $\mathrm{p}<0.001$ ). Buna ek olarak, ortalamanın üzerinde bir nütrisyonel bakım kalitesi algısı puanına sahip hemşirelerde, nütrisyonel bakıma ilişkin bilgi düzeyinin, hemşirelerin tutum puanlarındaki küçük düzeyde bir artışla ilişkili olan ikincil bir değişken olduğu görüldü $(r=$ $0.102, \mathrm{p}<0.013$ ).

Şekil 4'teki diyagram incelendiğinde, hemşirelerin nütrisyonel bakım kalitesi algılarını etkileyen en önemli değişkenin de, nütrisyonel değerlendirmenin önemine ilişkin hemşirelerin tutumları olduğu $(\mathrm{F}=32.792$; $\mathrm{p}<0.001)$ saptandi. Buna ek olarak nütrisyonel bakım bilgi düzeyinin, tutum puanı $25^{\prime}$ 'in üzerinde olan hemşirelerde, nütrisyonel bakım kalitesi puanlarındaki artışa katkı yapan üçüncül düzeyde bir değişken olduğu ancak bu ilişkinin pozitif yönde zayıf bir etkiye sahip olduğu saptandi $(r=0.090, p<0.028)$. 

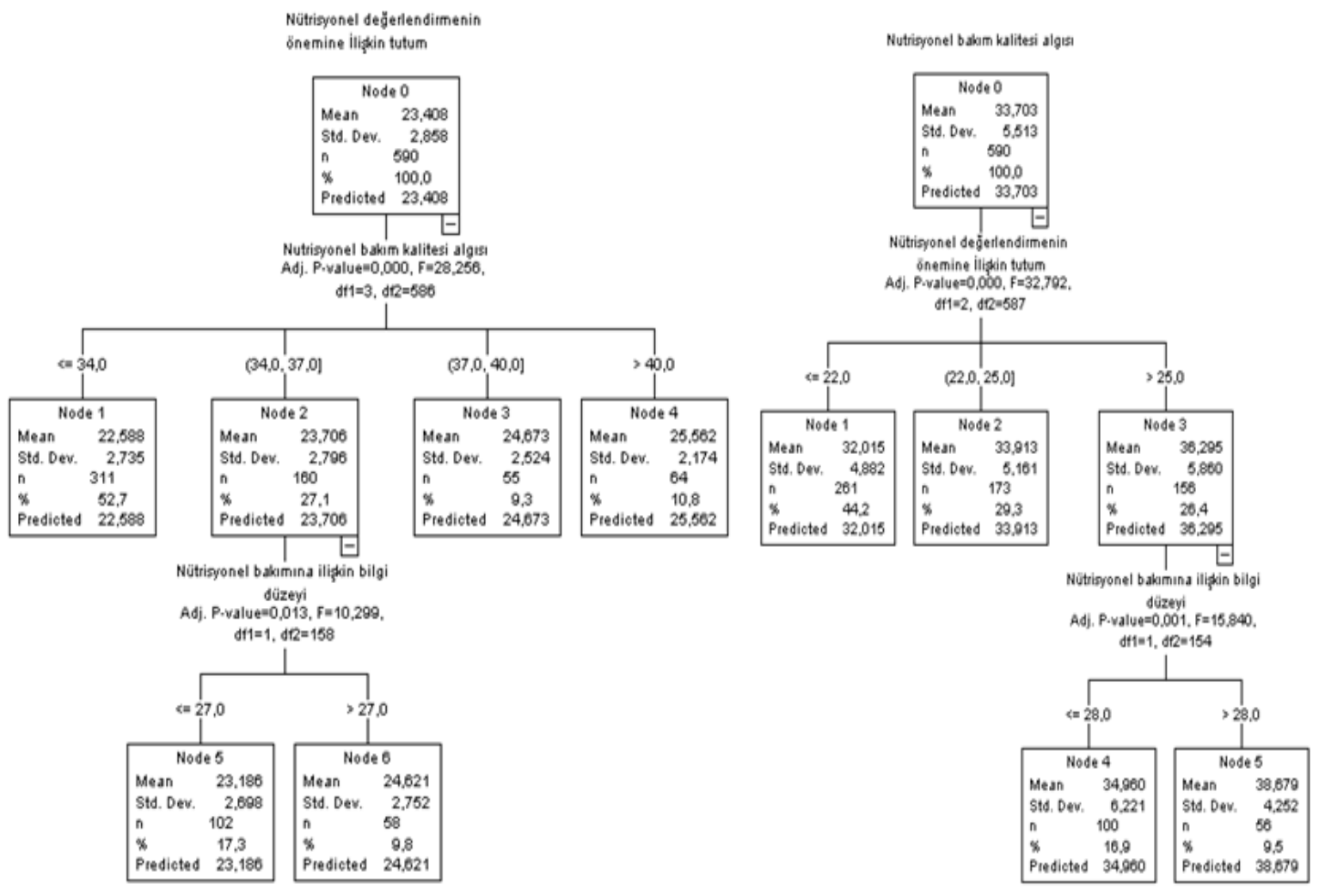

Şekil 4. Hemşirelerin tutum, bilgi düzeyi ve algılanan nütrisyonel bakım kalitesi puanlarının ilişkileri için ağaç diyagram1.

\subsection{Tartışma}

Nütrisyon desteği, tıbbi tedavi ve hasta bakımının önemli bir parçasıdır. Hemşirelerin, nütrisyon desteğine ihtiyaç duyan hastaları erken dönemde tanılayabilmesi ve hastanın nütrisyonel bakımında etkin olarak görev almaları, nütrisyon konusunda yeterli bilgi sahibi olmalarını gerektirir. Bu nedenle hemşirelerin nütrisyon desteğine yönelik bilgi düzeylerini geliştirmeyi amaçlayan eğitim faaliyetlerinin düzenlenmesi önemlidir [14]. Önceki literatür $[25,27,32]$ bulguları ile kıyaslandığında, bu çalışmada hemşirelerin çoğunluğunun (\%62.0) son bir y1l içinde nütrisyon desteğine yönelik eğitim aldığı saptanmıştır. Ülkemizde hemşirelerin nütrisyonel bakım alanına yönelik sorumluluklarının ön plana çıkarılmasını amaçlayan yasal düzenlemeler sonucunda, sağlık kuruluşları, hemşirelerin nütrisyon ile ilgili bakım rollerinin iyileştirilmesine yönelik başta eğitim çalışmaları olmak üzere, nütrisyon destek hemşirelerinin sertifikalandırılması gibi bir çok iyileştirme faaliyeti yürütmekte ve hemşirelerin nütrisyon desteğine yönelik rolleri daha fazla gündeme gelmektedir [28]. Eğitim müdahaleleri hemşirelerin nütrisyonel bakım konusundaki yeterliliklerini geliştirmek, hasta bakım sonuçlarında olumlu bir etki sağlamak ve hastaya sunulan bakım kalitesinin arttırılması için önemlidir. Konu ile ilişkili yapılan çalışmalar eğitimsel müdahalelerin, hemşirelerin nütrisyon desteğine yönelik bilgi düzeyi ve uygulamalarındaki iyileşmeye katkı sağlayabileceğini ortaya koymuştur [33-37]

Bu çalışmada elde ettiğimiz bir diğer bulgu, hemşirelerin çoğunluğunun nütrisyon desteğine yönelik eğitim almış olmalarına rağmen, üçte ikisine (\%71.9) yakınının nütrisyonel bakıma yönelik mevcut bilgilerini kısmen yeterli bulmasıdır. Duerksen ve ark. (2016) tarafindan yapılan çalışmada, hemşirelerin büyük çoğunluğu, nütrisyonel bakımla ilgili bilgilerinin güncellenmeye ihtiyaç duyduğunu ifade etmiştir [38]. Mowe ve ark. (2008) nütrisyonel bakıma ilişkin yetersiz uygulamaların en yaygın nedeninin, bilgi eksikliği olduğunu ortaya koymuştur [39]. Ameri ve ark. (2016) malnütrisyonla ilişkili olumsuz sonuçların önlenmesinde hemşirelik bilgisi ve uygulamaları arasındaki boşluğun kapatılmasının önemine dikkat çekmiştir [33]. Ancak ülkemizde hemşirelerle yürütülen bazı çalışmalarda da görüldüğü gibi hemşirelerin nütrisyon alanına yönelik bilgi ve uygulamalarının istendik düzeyde olmadığı bilinmektedir $[25,27,40]$. Bu bulgular, hemşirelerin 
nütrisyonel bakıma yönelik önemli rollerini yerine getirmeleri bakımından, hemşirelerin eğitim gereksinimlerinin belirlenmesinin ve profesyonel ve etkili eğitim müdahalelerinin gerekliliğinin önemini vurgulamaktadir.

Hastanede yatan hastalarda nütrisyonel durum değerlendirmesi ve hastanın ihtiyaç duyduğu nütrisyon desteğinin sağlanması sıklıkla ihmal edilmektedir $[12,18]$. Bu durumun en önemli nedenleri arasında, malnütrisyon riski altında olan hastaların zamanında ve doğru bir şekilde tespit edilememesi yer almaktadır $[1,15,19]$. Hemşireler risk altındaki hastaların tespit edilmesi ve kesintisiz nütrisyonel bakım için en uygun ekip üyeleridir [19,41,42]. Ancak, hemșirelerin kendinden beklenen bu rolü etkin olarak yerine getirmeleri, yeterli bir bilgi birikimini gerektirir. Yapılan bu çalışmada, hemşirelerin çoğunlukla, hastaların malnütrisyon riskinin değerlendirilmesi ve nütrisyon gereksiniminin hesaplanması konularında bilgi gereksinimlerinin olduğu belirlenmiştir. Bulgularımıza benzer şekilde, Mowe ve ark. (2008) tarafından yapılan çalışmada, yetersiz beslenmiş ya da malnütrisyon riski altındaki hastaları tanımlamada kullanılan yöntemler konusunda hemşirelerin orta seviyede bilgi düzeyine sahip oldukları, hastaların enerji ihtiyacını hesaplamakta zorlandıkları saptanmıştır [39]. Yapılan başka bir çalışmanın sonuçları, sağlık profesyonellerinin nütrisyon desteği ile ilgili daha fazla bilgi almak istedikleri alanın, hastanın besin ve enerji gereksiniminin hesaplanması olduğunu göstermiştir [43]. Norveç'te yapılan başka bir çalışmada, hemşireler, hastaların nütrisyonel durumunun nasıl değerlendirileceğinden emin olmadıklarını bildirmiştir [44]. $\mathrm{Bu}$ alana ilişkin hemşirelik uygulamalarının yetersiz kalması, malnütrisyon riski altındaki hastaların gözden kaçırılmasına ya da yanlış değerlendirmelerine yol açabilir. Bir Kore çalışması, hemşirelerin nütrisyon alanına yönelik bilgilerinin sınırlı olması nedeniyle, klinik ortamda nütrisyonel değerlendirmeye ilişkin kriterleri kötü kullandıklarını göstermiştir [20]. Çalışma bulgularımızda da belirlendiği edildiği gibi, nütrisyonel risk değerlendirmesi, hemşirelerin geliştirilmesine ihtiyaç duydukları bir bakım uygulamasıdır. $\mathrm{Bu}$ bulgu aynı zamanda hemşirelerin nütrisyonel risk değerlendirmesinin nasıl ve hangi yöntemlerle yapılması gerektiği konusunda bilgilendirilmeleri gerekliliğini de vurgulamaktadır.

Nütrisyonel bakım ile ilişkili uygulamaların iyileştirilmesi, hemşirelerin, nütrisyon konusunda olumlu bir tutuma sahip olmaları aynı zamanda da nütrisyonel değerlendirmeyi hemşirelik bakımının temel bir bileşeni olarak görmeleri ile mümkündür [15,20,45]. Yapılan bu çalışmada, nütrisyonel değerlendirmenin önemine ilişkin hemşirelerin olumlu bir tutuma sahip oldukları söylenebilir. Theilla ve ark. (2016) tarafından yapılan çalışmada, İsrailli hemşirelerin tutum puanı, bulgularımıza benzer olarak bulunmuştur [15]. Uluslararası literatürdeki benzer çalışmalar, nütrisyon desteğinin, kritik bir hastanın klinik sonuçlarına olumlu katkıda bulunacağını ve nütrisyonel durum değerlendirmesinin klinik önemine ilişkin hemşirelerin olumlu tutum sergilediklerini ortaya koymaktadır [20,43]. Ülkemizde hemşirelerin konu ile ilişkili tutumlarını değerlendiren çalışmaların sayısı çok sınırlı olmakla birlikte, Yılmaz ve ark.'nın (2017) çalışmasında hemşirelerin çoğunluğu, nütrisyonel değerlendirmenin hemşireler tarafından yapılamayacağını ve bu süreçte etkin rol almadıklarını bildirmiştir [25]. Aydın ve Karaöz'ün (2008) çalışmasında hemşirelerin önemli bir bölümü, hastanın nütrisyonel durumunun değerlendirilmesinin bir doktorun ya da diyetisyenin görevi olduğunu ifade etmiştir [26]. Bizim çalışmamızda hemşirelerin daha olumlu bir tutum sergilemeleri, nütrisyonel bakımın, hemşirelik uygulamalarının bir parçası olarak görülmesi konusundaki ülkemizdeki yasal düzenlemelerin ve konuya ilişkin hemşirelerin farkındalıklarının artmasının bir sonucu olabilir. Aynı zamanda çalışmamızdaki hemşirelerin olumlu tutumları, nütrisyonel bakım uygulamalarının iyileştirilmesine yönelik müdahalelere açık olduklarının da bir göstergesi olarak kabul edilebilir. Çalışma bulgularımız, yoğun bakım ünitesinde ve pediatri kliniğinde çalışmanın hemşirelerin tutum puanlarında etkili olan birincil değişkenler olduğunu göstermiştir. Bulgularımıza benzer şekilde, Kim ve Choue (2009), yoğun bakım ünitesinde çalışan Kore'li hemşirelerin, nütrisyonel değerlendirmenin önemine daha fazla değer verdiklerini bildirmiştir [20]. Bu sonuçlar, yoğun bakım ünitelerinde ve pediatri kliniklerinde çalışan hemşirelerin, hastaların kritik beslenme gereksinimleri ile ilişkili olarak nütrisyon desteğine yönelik uygulamalara daha fazla katılmaları ve bu alanlarda tedavi ve bakım altındaki hastalar için nütrisyonel gereksinim takibinin daha fazla gündeme gelmesi ile ilişkili olabilir. Bu çalışmada elde edilen bir diğer bulgu, tutum puanı anlamlı olarak daha yüksek olan hemşirelerde, nütrisyon desteğine yönelik eğitim almanın etkili olan bir diğer değișken olarak belirlenmesidir. Çalışmada elde ettiğimiz bilgi düzeyinin, hemşirelerin tutum puanlarındaki küçük düzeyde bir artışla ilişkili olduğunu gösteren sonucumuzda bu bulguyu desteklemektedir. Fjeldstad ve ark. (2017), hastanın nütrisyonel yönüne ilişkin sorumluluk alma yetersizliğinin, sağlık çalışanlarının nütrisyonla ilişkili bilgi boşluğundan kaynaklandığını vurgulamıştır [8]. Hastaların nütrisyonel gereksinimlerinin karşılanmasında kilit rol oynayan hemşirelerin nütrisyon ile ilişkili yeterlilikleri, nütrisyon desteği hakkındaki bilgilerine bağlıdır [14]. Literatür, profesyonel ve etkili eğitim müdahalelerinin, hemşirelerin nütrisyona yönelik farkındalıklarını ve yeterliliklerini arttırmaya, tutumlarını iyileştirmeye katkıda bulunduğunu dolayısıyla da hasta bakım sonuçlarına olumlu katkı sağladığını bildirmiştir $[15,36,37,46]$.

$\mathrm{Bu}$ çalışmada, hemşirelerin nütrisyonel bakıma ilişkin bilgi düzeylerinin istendik düzeyde olmadığ saptanmıştır. Theilla ve ark. (2016) İsrail'li hemşirelerin bilgi düzeyi puan ortalamalarını bizim bulgularımıza benzer olarak bildirmiştir [15]. Ülkemizde yapılan bir çalışmada, hemşire katılımcıların tamamının orta düzeyde bir bilgi puanı aldıkları saptanmıştır [14]. 
Hemşirelerin, nütrisyonel bakıma ilişkin rollerini yerine getirebilmelerinin bu konudaki bilgi düzeyleri ile ilişkili olduğu vurgulansa da hem uluslararası $[4,14,20,33,37,39,44,45]$ hem de ulusal $[14,25]$ alanda yapılan çalışmalar, nütrisyon desteği konusundaki bilgi eksikliğine ve hemşireler için kapsamlı nütrisyon desteği ve bakımı eğitimlerinin gerekliliğine vurgu yapmaktadır. $\mathrm{Bu}$ bulgular aynı zamanda hemşirelerin nütrisyonel bakıma ilişkin yeterliliklerinin ve farkındalıklarının geliştirilmesine, hemşirelik eğitim sürecinden itibaren başlanmasının da önemine dikkat çekmektedir. Bu çalışmada elde edilen bir diğer bulgu, nütriyonel desteğin sağlanmasında, hemşirelerin kendi sorumluluk alanlarına ilişkin bilgi puanın daha düşük olmasıdır. Hemşirelerin çoğunluğu (\%63.6) nütrisyon desteğinin bir hemşireden çok diyetisyenin sorumluluk alanı olduğunu ifade etmiştir. Literatür, nütrisyonel bakımın tıp, hemşirelik ve diyetetik arasındaki boşlukta kaldığını ve her bir meslek üyesinin, nütrisyonel bakımdaki sorumluluklarının yeterince açığa kavuşturulamadığına dikkat çekmiştir [47]. Eide ve ark. (2015) hastane ortamında nütrisyonel bakım stratejilerinin açıkça tanımlanmadığı sistemsel sorunların, nütrisyonel bakımda ihmale yol açan önemli bir faktör olduğunu vurgulamıştır [44]. Çalışmamızda, hemşirelerin bilgi düzeyine ilişkin olarak elde edilen bir diğer bulgu, hastanın yemeğini yememesinin olası nedenine ilişkin hemşirelerin bilgi puanının daha düşük olmasıdır. Yapılan bir çalışmada, nütrisyonel bakımın, hemşireler tarafından sadece, hastanın yeme-içme durumu ya da yeme alıșkanlıkları olarak algılandığına da dikkat çekilmiştir [26]. Bu bulgular, hastanın nütrisyonel durumuna katkı yapabilecek ya da besin alımını olumsuz etkileyebilecek tıbbi durumu ile ilişkili diğer faktörlerin gözden kaçırılmasına yol açabilir.

$\mathrm{Bu}$ çalışmada hemşirelerin nütrisyonel bakım bilgi düzeyine yönelik elde ettiğimiz bir diğer bulgu hemşirelerin eğitim düzeyinin, bilgi puanlarını etkileyen birincil değişken olarak belirlenmesidir. Bulgularımıza benzer şekilde, Yalcin ve ark. (2013) orta öğretim düzeyindeki hemşirelerle kıyaslandığında, lisans ve lisansüstü mezun hemşirelerin, daha yüksek nütrisyon bilgi puanına sahip olduklarını bildirmiştir [14]. Avusturya'da yapılan bir çalışmada, lisans mezunu hemşirelerin, daha düşük eğitim düzeyindeki hemşire yardımcılarına kıyasla nütrisyon desteğine ilişkin daha fazla bilgiye sahip oldukları saptanmıștır [45]. Theilla ve ark. (2016) eğitim düzeyindeki artışın, nütrisyonel bakım bilgisinin önemli bir belirleyicisi olduğunu bildirmiştir [15]. Her ne kadar bu çalışmada hemşirelerin eğitim düzeylerindeki artış, nütrisyonel bakım bilgi düzeyine katkı yapan bir faktör olarak belirlense de çalışma bulgularımız bu etkinin küçük bir artışa katkı sağlayabildiğini de göstermiştir. Bu durum, Türkiye'deki hemşirelik eğitim müfredatında nütrisyona yönelik bir bilgi boşluğu ile de ilişkili olabilir. Araştırma kapsamına dahil edilen hemşirelerin neredeyse yarısına yakının nütrisyonla ilgili bilgi kaynaklarını uygulama alanındaki deneyimlerine dayandırması da bu düşüncemizi desteklemektedir. Türkiye'de yapılan bazı çalışmalarda da nütrisyona yönelik bilgi düzeyinin hemşirelerin eğitim durumlarına göre farklılık göstermediği belirlenmiştir [27,32]. Çalışmamızda, lisans ve lisansüstü eğitim düzeyindeki hemşireler arasında, devlet hastanesinde çalışıyor olmanın hemşirelerin bilgi düzeyi puanlarını etkileyen bir değişken olduğu belirlense de kurumlar arasındaki bu farklılığın küçük bir etki büyüklüğüne sahip olduğu görülmüştür. Bu bulgu, nütrisyonel bakıma ilişkin uygulamaların kurumlar arasındaki işlerliğinin farklılığından kaynaklanıyor olabilir.

Sağlık bakım ortamlarında, hastalara sunulan nütrisyonel bakım uygulamalarının, klinik klavuzlar tarafından vurgulanmış olan öneriler ve yönergeler ile uyumlu olması, güvenli ve kaliteli nütrisyonel bakımının temelini oluşturur [48]. $\mathrm{Bu}$ nedenle hemşirelerin, hastalara sunulan nütrisyonel bakımın kalitesini nasıl algıladıkları ve değerlendirdikleri önemlidir [20,21]. Bu çalışmada, hemşirelerin nütrisyonel bakım kalitesi algısı puan ortalamaları, kendi kliniklerinde hastalara sunulan nütrisyonel bakımının kalitesini yeterince olumlu olarak değerlendirmediklerini göstermektedir. $\mathrm{Bu}$ aynı zamanda, klinik ortamda hastalara sunulan nütrisyonel bakımın istendik düzeyde olmadığının da bir göstergesi olarak yorumlanabilir. İdeal bir nütrisyonel bakımın ilk adımı, hastaneye yatışın hemen ardından hastaların malnutrisyon riski açısından taranması ve nütrisyonel yeterliliğinin değerlendirilmesidir [5]. Ancak bulgularımız, nütrisyonel değerlendirmeye ve nütrisyon desteğinin düzenli ve profesyonelce sunulmasına ilişkin hemşirelerin bakım kalitesi algısı puanlarının daha düşük olduğunu ortaya koymuştur. Yılmaz ve ark.'nın (2017) çalışmasında katılımcı hemşirelerin sadece beşte biri, kendi kliniklerinde hastaların nütrisyonel yönünün ele alındığını ifade etmiştir [25]. Ekincioğlu ve ark. (2017) çalışmalarında nütrisyon desteğinin yönetimine ilişkin hekim ve hemşirelerin farklı bakış açılarına sahip olduğuna dikkat çekmiştir [49]. Yapılan bazı çalışmalarda da hastaların nütrisyonel yönünün yeterince ele alınmadığ 1 bildirilmiştir [3,41]. Bu bulgular aynı zamanda, nütrisyonel bakım ve nütrisyon desteğine yönelik uygulamaların, kurumsal işleyişinin mevcut durumundaki yetersizliklerinde bir sonucu olarak düşünülebilir. Bu bulguların, hastanede yatan hastalarda beslenme ilişkili olumsuz klinik sonuçlara yol açabileceği göz önünde bulundurulduğunda, ülkemizde nütrisyonel bakım ve nütrisyon desteği ile ilişkili uygulamaların profesyonel ekip işbirliği içinde sunulmasının daha fazla çaba gerektirdiği açıktır. Çalışma bulgularımız, yoğun bakım ünitesinde çalışmanın, hemşirelerin nütrisyonel bakım kalitesi algıları için orta düzeyde bir artışa katkı sağladığını göstermiştir. $\mathrm{Bu}$ bulgu, yoğun bakım ünitesindeki hastalar için nütrisyon desteği uygulamalarının kritik öneme sahip olması, dolayısıyla nütrisyonel uygulamalara yoğun bakım ünitelerinde daha fazla önem ve yer verilmesinin de bir sonucu olabilir. Kritik hastaların yakından takip edildiği yoğun bakım üniteleri, malnütrisyon riski ile en yaygın karşılaşılan ortamdır [50]. Hemşireler, beslenme ürünlerini uygulamaktan sorumlu olmaları nedeni ile de nütrisyonel destek kalitesinin hem iyileştirilmesinde hem de 
değerlendirilmesinde gözlemlerinden ve katkılarından yararlanılabilecek en önemli ekip üyesi olarak kabul edilmektedir [51]. Çalışma bulgularımız hemşirelerin nütrisyonel bakım kalitesi algısı puanlarında ikincil düzeyde etkili olan bağımsız değişkenin devlet hastanesinde çalışmak olduğunu göstermiştir. Türkiye'de Sağlık Bakanlığına bağlı devlet hastanelerinde kurumsal kültürün bir parçası olarak Kalite Standartlarına ilişkin çalışma ve uygulamaların geçmişi daha eskilere dayanmaktadır. Dolayısıyla bir hasta bakım standardı olarak da yeterliliği değerlendirilen nütrisyon desteğinin, profesyonel bir nütrisyon destek ekibi tarafından devlet hastanelerinde daha uzun süredir sağlanıyor olması nütrisyonel bakım kalitesinin devlet hastanesinde çalışan hemşireler tarafindan daha olumlu değerlendirilmesine katkı sağlamış olabilir. Theilla ve ark. (2016) çalışmalarında, hemşirelerin nütrisyonel bakım kalitesi algılarının, nütrisyonun önemi ile ilişkili bilgilerine dayandığını bildirmiştir [15]. Bu çalışmanın bulgularında da benzer şekilde hemşirelerin nütrisyonel bakım bilgi düzeylerindeki artışın, tutum puanlarına olan pozitif katkısının, hemşirelerin nütrisyonel bakım kalitesi algılarındaki artışa katkı yapan bir değişken olduğu saptanmıştır. Bu bulgu aynı zamanda, daha iyi bir nütrisyonel bakım bilgisi ile, hemşirelerin de hastalara sunulan nütrisyonel bakımı daha doğru değerlendirebilecekleri dolayısıyla nütrisyonel bakım kalitesinin iyileştirilmesine yönelik daha fazla çaba gösterebilecekleri anlamında da yorumlanabilir.

\section{7. Çalışmanın Kısıtlılıkları ve Güçlü Yönleri}

$\mathrm{Bu}$ çalışmanın en önemli kısıtlılığı, araştırmanın yapıldığı örneklem ile sınırlı olmasıdır. Dolayısı ile araştırmadan elde edilen bulgular bu örnekleme genellenebilir. Çok merkezli ve daha büyük örnekleme sahip çalışmalarla tekrarlanması önerilmektedir. Bununla birlikte ülkemizdeki hastaların nütrisyonel durumlarının değerlendirilmesinin önemine ilişkin hemşirelerin tutumlarını, nütrisyonel bakım bilgi düzeylerini ve nütrisyonel bakım kalitesi algılarını değerlendirmeye yönelik yapılan ilk çalışma olması ile literatüre katkı sağlamıştır. Bu durum, çalışmamızın güçlü yönünü oluşturmaktadır.

\section{Sonuç}

$\mathrm{Bu}$ çalışmadan elde edilen sonuçlar, nütrisyonel değerlendirmenin önemine ilişkin hemşirelerin tutumlarının olumlu olduğunu ancak davranışın eyleme geçirilmesi ve hasta bakım sonuçlarına yansıması için, hemşirelerin malnütrisyon risk değerlendirmesi ve nütrisyonel bakım uygulamalarına ilişkin bilgi gereksinimlerinin olduğunu ortaya koymuştur. Bu sonuçlar hemşirelerin bilgi eksikliklerini arttırmaya yönelik eğitim müdahalelerinin gerekliliğini vurgulamaktadır. Bununla birlikte nütrisyonel değerlendirmeyi hemşirelik bakımının temel bir bileşeni olarak kabul eden ve daha iyi bir nütrisyonel bakım bilgisine sahip hemşirelerin, klinik alanda hastalara sunulan nütrisyonel bakımın kalitesinin iyileştirilmesine daha fazla katkı sağlayabileceği düşünülmektedir. Bu sonuçlar doğrultusunda, temel hemşirelik eğitiminden itibaren, beslenmenin, hemşirelik uygulamalarının önemli bir parçası olarak kabul edilmesi, nütrisyonel bakımda hemşirelerin rol ve sorumluluklarının daha fazla ele alınması, hemşirelerin mezuniyet sonrasında da beslenme durum değerlendirmesi ve bakımına ilişkin bilgi ve uygulamalarının geliştirilmesi gereklidir. Hasta bakım standartlarının yeterliliğini değerlendiren, hemşirelerin nütrisyonel bakımda daha fazla görev ve sorumluluk almalarını sağlayan, hemşirelerin nütrisyonel bakımdaki yetkinliklerini destekleyen kurumsal ve mesleki iyileştirmelerin yapılması önerilmektedir.

\section{Teşekkür}

Bu araştırmaya katılarak katkı sağlayan tüm hemşirelere ve araştırmanın yapılmasına izin veren kurum yöneticilerine teşekkür ederiz.

\section{Referanslar}

1.Shin, B.C, Chun, I.A, Ryu, S.Y, Oh, J.E, Choi, P.K, Kang, H.G, Association between indication for therapy by nutrition support team and nutritional status, Medicine (Baltimore), 2018, 97(52),1-5.

2. Marshall, A.P, Takefala, T, Williams, L.T, Spencer, A, Grealish, L, Roberts, S, Health practitioner practices and their influence on nutritional intake of hospitalised patients, International Journal of Nursing Sciences, 2019, 6(2), 162-168.

3. Sun, H, Zhang, L, Zhang, P, Yu, J, Kang, W, Guo, S, et al, A comprehensive nutritional survey of hospitalized patients: Results from nutrition Day 2016 in China, PLoS One, 2018, 13(3), e0194312.

4. Al-Kalaldeh, M, Watson, R, Hayter, M, Jordanian nurses' knowledge and responsibility for enteral nutrition in the critically ill, Nursing in Critical Care, 2015, 20(5), 229-241.

5. Meijers, J.M, Tan, F, Schols, J.M, Halfens, R.J, Nutritional care; do process and structure indicators influence malnutrition prevalence over time? Clinical Nutrition, 2014, 33(3), 459-465.

6. Alzahrani, S.H, Alamri, S.H, Prevalence of malnutrition and associated factors among hospitalized elderly patients in King Abdulaziz University Hospital, Jeddah, Saudi Arabia, BMC Geriatrics, 2017, 17(1),136.

7. Curtis, L.J. Bernier, P. Jeejeebhoy, K. Allard, J, Duerksen, D, Gramlich, L. et al, Costs of hospital malnutrition. Clinical Nutrition 2017, 36(5), 1391-1396.

8. Fjeldstad, S.H, Thoresen, L, Mowé, M, Irtun, Ø, Changes in nutritional care after implementing national guidelines-a 10-year follow-up study, The European Journal of Clinical Nutrition, 2018, 72(7), 1000-1006

9.Leiva, B.E, Badia, T.M, Virgili, C.N, Elguezabal, S.G, Faz, M.C, Herrero, M.I. et al, Hospital malnutrition screening at admission: malnutrition increases mortality and length of stay, Nutricion Hospitalaria, 2017, 34(4), 907-913.

10. Avelino-Silva, T.J, Jaluul, O, Malnutrition in hospitalized older patients: management strategies to improve patient care and clinical outcomes, International Journal of Gerontology, 2017, 11, 56-61.

11. Christner, S, Ritt, M, Volkert, D, Wirth, R, Sieber, C.C, Gaßmann, K.G, Evaluation of the nutritional status of older hospitalised geriatric patients: a comparative analysis of a Mini Nutritional Assessment (MNA) version and the Nutritional Risk Screening (NRS 2002), Journal of Human Nutrition and Dietetics, 2016, 29(6), 704713

12. Kang, M.C, Kim, J.H, Ryu, S.W, Moon, J.Y, Park, J.H, Park, J.K, et al, Prevalence of malnutrition in hospitalized patients: a multicenter cross-sectional study, Journal of Korean Medical Science, 2018 33(2), 1-10

13. Valentini, A, Federici, M, Cianfarani, M.A, Tarantino, U, Bertoli, A, Frailty and nutritional status in older people: the Mini Nutritional Assessment as a screening tool for the identification of frail subjects, Clinical Interventions in Aging, 2018, 13, 1237-1244.

14. Yalcin, N, Cihan, A, Gundogdu, H, Ocakci, A, Nutrition knowledge level of nurses, Health Science Journal, 2013, 7(1), 99-108.

15. Theilla, M, Cohen, J, Singer, P, Liebman, C, Kagan, I. et al, The Assessment, knowledge and perceived quality of nutrition care 
amongst nurses, Journal of Nutritional Medicine and Diet Care, 2016, 2(1), 2-5.

16. Muscaritoli, M, Krznarić, Z, Singer, P, Barazzoni, R, Cederholm, T, Golay, A. et al, Effectiveness and efficacy of nutritional therapy: A systematic review following Cochrane methodology. Clinical Nutrition, 2017, 36(4), 939-957.

17. Rinninella, E, Fagotti, A, Cintoni, M, Raoul, P, Scaletta, G Quagliozzi, L. et al, Nutritional interventions to improve clinical outcomes in ovarian cancer: a systematic review of randomized controlled trials, Nutrients, 2019, 11(6), 1404.

18. Barker, L.A, Gout, B.S, Crowe, T.C, Hospital malnutrition: prevalence, identification and impact on patients and the healthcare system, International Journal of Environmental Research and Public Health, 2011, 8(2), 514-527.

19. Sauer, A.C, Alish, C.J, Strausbaugh, K, West, K, Quatrara, B, Nurses needed: Identifying malnutrition in hospitalized older adults, Nursing Plus Open 2, $2016,21-25$.

20. Kim, H, Choue, R, Nurses' positive attitudes to nutritiona management but limited knowledge of nutritional assessment in Korea, International Nursing Review, 2009, 56(3), 333-339.

21. Mogre, V, Ansah, G.A, Marfo, D.N, et al, Assessing nurses' knowledge levels in the nutritional management of diabetes, International Journal of Africa Nursing Sciences, 2015, 3, 40-43.

22. Chapman, C, Barker, M, Lawrence, W, Improving nutritional care: innovation and good practice, Journal of Advanced Nursing, 2015 71(4), 881-94.

23. Sağlıkta Kalite Standartları Hastane Seti, 2015 , https://dosyamerkez.saglik.gov.tr/Eklenti/3460,skshastanesetiv5r1p df.pdf? Erişim Tarihi: 1 Şubat 2010.

24. Hemşirelik Yönetmeliğinde Değişiklik Yapılmasına Dai Yönetmelik, $19 \quad$ Nisan 2011. http://www.turkhemsirelerdernegi.org.tr/tr/yasa-veyonetmelikler/yonetmelikler/19-nisan 2011-hemsirelikyonetmeliginde-degisiklik-yapilmasina-dair-yonetmelik.aspx. Erişim Tarihi: 1 Şubat 2010.

25. Yılmaz, D.K, Sarkut, P, Düzgün, F, Kuzu, C, Kılıçturgay, S, Yatan hastaların nutrisyonel değerlendirme ve desteğine yönelik hemşirelerin görüşleri, Hemşirelikte Eğitim ve Araştırma Dergisi, 2017, 14(2), 139-143.

26. Aydin, N, Karaöz, S, Nutritional assessment of patients before gastrointestinal surgery and nurses' approach to this issue, Journal of Clinical Nursing, 2008, 17(5), 608-617.

27. Koçhan, E, Akın, S, Hemşirelerin enteral ve parenteral beslenme uygulamalarına ilişkin bilgi düzeylerinin değerlendirilmesi, JAREN 2018, 4(1), 1-14.

28. Kisacık, G.Ö, Coş̆un, T, Taștekin, A, Hemșirelerde nütrisyone değerlendirmenin önemini, nütrisyonel bakıma ilişkin bilgi düzeyin ve algılanan nütrisyonel bakım kalitesini değerlendirme ölçeğ Türkçe formunun psikometrik özellikleri, Ege Üniversitesi Hemşirelik Fakültesi Dergisi, 2019, 35(3), 123-135.

29. Sata, M, Caka, M, CHAID Analizi ve lojistik regresyon analiz sonuçlarının karşılaştırılması, Dicle Üniversitesi Ziya Gökalp Ĕ̈itim Fakültesi Dergisi, 2018, 33, 48-56.

30. Doğan, N, Özdamar, K, CHAID analizi ve aile planlaması ile ilgili bir uygulama, Türkiye Klinikleri Tip Bilimleri, 2003, 23, 392-397.

31. Cohen, J, Statistical Power Analysis for the Behavioral Sciences, 1988, New York, NY: Routledge Academic.

32. Özbaş, N, Göçmen, B.Z, Hemşirelerin tüple enteral beslenme konusunda bilgi düzeylerinin belirlenmesi, Journal of Human Sciences, 2018, 15(1), 359-367

33. Ameri, Z.D, Vafaee, A, Sadeghi, T, Mirlashari, Z, Ghoddoosi-Nejad, D, Kalhor, F, Effect of a comprehensive total parenteral nutrition training program on knowledge and practice of nurses in NICU, Global Journal of Health Science, 2016, 8(10), 135-142

34. Ke, L.S, Chiu, T.Y, Hu, W.Y, Lo, S.S, Effects of educationa intervention on nurses' knowledge, attitudes, and behavioral intentions toward supplying artificial nutrition and hydration to terminal cancer patients, Support Care Cancer, 2008, 16(11), 1265 1272.

35. Khalil El-Meanawi, N.H.K, Impact of implementing an educationa program regarding care of nasogastric tube feeding on nurses' knowledge and performance, Journal of Nursing and Health Science, 2017, 6(1), 101-109.

36. Kim, H, Chang, S.J, Implementing an educational program to improve critical care nurses' enteral nutritional support, Australian Critical Care, 2019, 32(3), 218-222.

37. Sharour, L.A, Improving oncology nurses' knowledge, selfconfidence, and self-efficacy in nutritional assessment and counseling for patients with cancer: A quasi-experimental design, Nutrition, 2019, 62, 131-134.

38. Duerksen, D.R, Keller, H.H, Vesnaver, E, Laporte, M, Jeejeebhoy, $\mathrm{K}$, Payette, $\mathrm{H}$, et al., Nurses' perceptions regarding the prevalence, detection, and causes of malnutrition in Canadian hospitals: results of a Canadian malnutrition task force survey, The Journal of Parenteral and Enteral Nutrition, 2016, 40(1), 100-106.

39. Mowe, M, Bosaeus, I, Rasmussen, H.H, Kondrup, J, Unosson, M, Rothenberg, E. et al., Insufficient nutritional knowledge among health care workers? Clinical Nutrition, 2008, 27(2), 196-202.

40. Uysal, N, Esser, İ, Khorsid, L, Hemsirelerin Enteral Beslenme İslemine Yönelik Uygulama ve Kayıtlarının İncelenmesi, Anadolu Hemşirelik ve Sağlık Bilimleri Dergisi, 2011, 14(2), 1-9.

41. DeLegge, M.H, Kelly, A.T, State of nutrition support teams, Nutrition in Clinical Practice, 2013, 28(6), 691-697.

42. Khalaf, A, Westergren, A, Ekblom, O, Al-Hazzaa, M.H, Berggren, $\mathrm{V}$, Nurses' views and experiences of caring for malnourished patients in surgical settings in Saudi Arabia - a qualitative study, BMC Nursing, 2014, 13, 29.

43. Lane, C, Wedlake, L.J, Dougherty, L, Shaw, C, Attitudes towards and knowledge of nutrition support amongst health care professionals on London intensive care units, Journal of Human Nutrition and Dietetics, 2014, 27(Suppl 2), 339-351

44. Eide, H.D, Halvorsen, K, Almendingen, K, Barriers to nutritional care for the undernourished hospitalised elderly: perspectives of nurses, Journal of Clinical Nursing, 2015, 24(5-6), 696-706.

45. Bauer, S, Halfens, R.J, Lohrmann, C, Knowledge and attitudes of nursing staff towards malnutrition care in nursing homes: A multicentre cross-sectional study, The Journal of Nutrition, Health \& Aging, 2015, 19(7), 734-740.

46. Alhashemi, S.H, Ghorbani, R, Vazin, A, Improving knowledge, attitudes, and practice of nurses in medication administration through enteral feeding tubes by clinical pharmacists: a case-control study, Advances in Medical Education and Practice, 2019, 10, 493-500.

47. Jefferie, D, Johnson, M, Ravens, J, Nurturing and nourishing: the nurses' role in nutritional care, Journal of Clinical Nursing, 2011 20(3-4), 317-330.

48. Persenius, M, Hall-Lord, M.L, Wilde-Larsson, B, Carlsson, E, Clinical nursing leaders' perceptions of nutrition quality indicators in Swedish stroke wards: a national survey, Journal of Nursing Management, 2015, 23(6), 705-715.

49. Ekincioğlu, B.A, Kelleci, B, Surmelioglu, N, Hawes, E, Demirkan, K, Halil, M, Abbasoğlu, O, Practice Perspectives of Healthcare Professionals Regarding Common Dilemmas Associated with Enteral Nutrition, Journal of Critical and Intensive Care, 2017, 8(2), 44-49.

50. Vest, M.T, Kolm, P, Bowen, J, et al., Association between entera feeding, weight status, and mortality in a medical intensive care unit, American Journal of Critical Care, 2018, 27(2), 136-143.

51. Mula, C, Nurses' competency and challenges in enteral feeding in the intensive care unit (ICU) and high dependency units (HDU) of a referral hospital, Malawi, Malawi Medical Journal, 2014, 3(26),5559.

http://edergi.cbu.edu.tr/ojs/index.php/cbusbed isimli yazarın CBU-SBED başlıklı eseri bu Creative Commons Alıntı-Gayriticari4.0 Uluslararası Lisansı ile lisanslanmıştır 